\title{
LITHUANIAN AND LATVIAN URBAN YOUTH PERCEPTIONS AND STEREOTYPES OF FARMER AND AGRICULTURE
}

\author{
Janis Kusis ${ }^{1}$, Baiba Miltovica ${ }^{2}$, Linda Feldmane ${ }^{3}$ \\ Latvian University of Agriculture, Institute of Social and Human Sciences (Latvia)
}

\begin{abstract}
The article examines the theoretical approach of the terms stereotypes and occupational stereotyping. The term "stereotype" is seldom encountered in the sociological or economical papers dealing with farmer, farming and agriculture. There are existing differences of characteristics of stereotypes therefore article will try to detect features described by W. Lipmann, R. Dyer, S. Oskamp, R. W. Schultz and others. Some of the definitions offer thought that stereotypes are oversimplifications or generalizations while they are more complicated as it seems from the first sight. The current article will discover sociological concern of how stereotypes function in social thought and the specific concerns how stereotypes function in urban youth thoughts. Article will distinguish negative, neutral and positive stereotypes. The article will include both qualitative and quantitative research methods in order to reveal Lithuanian and Latvian urban youth perceptions and stereotypes of Farmer and Agriculture.
\end{abstract}

KEY WORDS: stereotype, occupational stereotype, urban youth.

JEL CODE: Q18

DOI: http://dx.doi.org/10.15181/rfds.v14i3.871

\section{Introduction}

Agriculture in Europe is expected to fulfill a variety of functions. It contributes to the supply of European citizens with safe and high quality food in a competitive market, to maintain valuable cultural landscapes across Europe through sustainable land management and to help rural areas to remain attractive. At the same time, agriculture is undergoing fundamental changes which require farmers to adapt to new conditions and seize new opportunities (European Commission, 2009: 1). While Europe's rural communities are under threat. With farmers' incomes only about half the average EU wage, it's no surprise that over the last decade agricultural employment fell by 25 percent. Every year Europe has 2 percent fewer farmers. Around 60 percent of the EU population lives in the countryside which covers 90 percent of the Union's territory. The countryside is one of our greatest and farmers need help to protect the rural environment and way of life (Debating Europe, 2014: 1).

1 Janis Kusis - doctor hist., associate professor, Latvian University of Agriculture, Faculty of Economics and Social Development, Institute of Social and Human Sciences, Sociology

E-mail: Janis.Kusis@1lu.lv

Tel.: +0037126747436

2 Baiba Miltovica - Mg. sc. pol., Latvian University of Agriculture, Faculty of Economics and Social Development, Institute of Social and Human Sciences, Politology

E-mail: Baiba@zemgalei.lv

Tel.: +0037129441961.

3 Linda Feldmane - Mg. sc. soc., Latvian University of Agriculture, Faculty of Economics and Social Development, Institute of Social and Human Sciences, Sociology

E-mail: Linda.Feldmane@1lu.lv

Tel.: +0037129440601 
In the context of the importance of the agriculture it is essential to raise understanding within society that agriculture is particularly significant for economic development. Almost half of all agricultural workers are 55 years or older. At EU-27 level there is approximately 1 farmer of less than 35 years old for each 9 farmers of more than 55 years (Young Farmers Statistics, 2014). Therefore it is essential to raise awareness and popularity within youth as regards farming and agriculture.

The aim of the article is to discover sociological concern of stereotypes (by W. Lipmann, R. Dyer, S. Oskamp, R. W. Schultz) function in social thought and the specific concerns how stereotypes function in urban youth thoughts. The tasks of the article:

- to discover theoretical aspects of sociological stereotype backgrounds;

- to reveal Lithuanian and Latvian urban youth perceptions of farmer and agriculture;

- to analyze expert views of youth perceptions and agriculture sector issues.

The both qualitative and quantitative research methods where applied to identify Latvian urban youth perceptions of farmer and agriculture. In the first pilot phase of the research a focus group discussion was been conducted with participation of urban city youth. In total there were 9 youth, age 20-26 representing different gender, both from the last classes of the secondary schools and the first and second year students at university. The focus group role was to pick up the most widespread stereotypes about farmer and agriculture that will be used at the next steps of the research.

The next step in the research concerned quantitative research approach based on the urban youth survey to define and analyze the first phase of the research findings - identification of the Lithuanian and Latvian urban youth perceptions of farmer and agriculture. The urban youth survey was been carried out in the secondary schools and universities of the urban cities in Lithuania and Latvia by applying availability sampling (950 urban youth from Latvia - Jelgava, Daugavpils, Liepaja, Riga where universities are schools are available and 908 from Lithuania - Vilnius, Kaunas, Panevėžys, Klaipėda where universities are schools are available).

An availability sample is often appropriate in social research - for example, when a field researcher is exploring a new setting and trying to get some sense of the prevailing attitudes or when a survey researcher conducts a preliminary test of a new set of questions (Engel, 2009: 122). Elements are selected for availability sampling because they're available or easy to find respondents in the classes of the secondary schools or the first and the second year students at university.

The current article analyses students' responses to the questionnaire and explores wider issues relating to stereotyping and occupational stereotyping discussing the interpretation of these concepts. Results suggest that pupils and students held both positive and negative assumptions about specific occupations such as farmer. Further qualitative research methods where applied to identify EU Member States agricultural policy expert opinions of youth perceptions and agriculture sector issues, to describe how stereotypic views arise and what determines such perceptions. There where made interviews with agricultural policy experts in 12 EU Member States. By using a combination of qualitative and quantitative data was been possible to improve an evaluation by ensuring that the limitations of one type of data are balanced by the strengths of another.

\section{Research theoretical approach}

Stereotypes vary in their nature and significance, in their way of expression while it also creates stamps and they concern tolerance of the society. In accordance with the Edinburgh University professor R. Dyer the term "stereotype" is today almost always a term of abuse. This stems from the wholly justified objections of various groups in recent years, blacks, women and gays, in particular to the ways in which they find themselves stereotyped in the mass media and in everyday speech (Dyer, 1999: 1). Stereotypes are characteristics ascribed to groups of people involving occupation, gender, national origin and other factors. These characteristics tend to be oversimplifications of the groups involved. 
The term stereotype was first introduced to the social sciences by the American journalist Walter Lippmann in 1922. According to Lippmann, stereotypes are employed to help impose order onto a complex world. They present a shortcut in the processing of data, which, in his words, "precedes the use of reason". Stereotypes are seen as dependent on cultural traditions, group interests, and the differentiation of the ingroup from outsiders. As Dyer concludes even school children hold stereotypes about ethnic groups, perhaps largely because of the effect of mass media (Seite, 2006: 14). Indeed, mass media play a role in stereotypes, though it is more a case of reinforcing rather than creating stereotypes.

According to W. B. Helmreich stereotypes are most often exaggerations or distortions of reality, they are often accepted by people as fact. When people employ stereotypes they are usually making judgments about a given individual's potential to fit into a certain category based upon that person's professional, racial or ethnic origins.

Another cause of stereotypes may be the cultural background of the individual. Most cultures encourage prejudiced attitudes toward other groups. These attitudes are integrated in people beginning with early childhood, and are therefore very difficult to overcome. In general, the longer one has such attitudes, the harder it is to change them. In many cases, people select minority group members as scapegoats because they are powerless, relatively speaking and/or easily identifiable (Helmreich, 2004: 4). The Helmreich reflected very important point that importance of developing stereotypes start from the early childhood and youth age is important period when formal and non formal activities of the education, leisure time and hobby can reflect certain cultural background that can influence change of stereotypic thinking.

There are exists various explanations of the term „stereotypes” while one of the most commonly used are thought or assumption that may be adopted about specific types of individuals while these thoughts or beliefs may or may not accurately reflect reality (Lipmann, Dyer, Oskamp, Schultz). In order to reveal the essence of the stereotypes it is important to describe the characteristics of stereotypes.

Four characteristics of stereotypes:

1. Simple: They're far more simple than reality and often expressed in two to three sentences.

2. Acquired second hand: we acquire (and absorb) stereotypes from cultural mediators (like the mass media) rather than from our own direct experience with the stereotyped groups. The culture "distils" reality and then expresses its beliefs and values in stereotypical images that convince audiences of the "truth" of the stereotype by placing it in a carefully controlled context in which there is a measure of truth to the image: for example, "Of course women can and should be thin and beautiful: Look at Julia Roberts!..”

3. Erroneous: All stereotypes are false - although some are less false than others, and more (more importantly) some are less harmful than others. Because they claim that each and every individual human being in a certain group shares a set of common qualities, stereotypes are a logical impossibility. Even countertypes presented as the "new" truth about a group are false unless presented as possibilities rather than actualities.

4. Resistant to change: Even through race and sex inequalities have alerted most of us to the tragic consequences of stereotypes, old stereotypes nevertheless still colors our perceptions. Fortunately, stereotypes can change when we decide to break the mold and recast those pictures in our heads (Analysis and criticism, 2013: 35).

Because stereotypes is simple way to imagine or get picture of something not existing it is more easy way for urban youth to acquire them. Cultural mediator like mass media is having potential to reinforce stereotypes. It is a commonplace that the mass media are populates stereotypes. They strongly supported by some of the society members and widely distributed.

Lippmann also observed a social function of stereotyping, namely, as a "projection upon the world of our own sense of our own value, our own position and our own rights" (Lipmann, 1998: 79). The some other theoreticians like Oskamp and Schultz did described stereotype as "picture in our heads" about various ra- 
cial, national or social group - that is perceptions of members of a given group as all being identical copies of each other, all having the same characteristics and traits (Oskamp, Schultz, 2009: 304).

In accordance with Dyer term "stereotypes" where developed particularly stressing stereotypes as:

- an ordering process;

- a , short cut';

- referring to ,the world';

- expressing values and beliefs (Dyer, 1999: 1).

The current paper will discover sociological concern of Lippmann, Dyer, White, Hinton and others in order to describe how stereotypes functions in social thought and the specific concerns how stereotypes function in urban youth thoughts. The position behind all these considerations is that it is not stereotypes, as an aspect of human thought and representation, therefore it is important to discover how they are served in accordance with the occupational stereotyping of farmer portrait.

\section{Stereotypes and Occupational stereotyping}

The inherent problem is that a general stereotype influences the way we think and talk about individual members of a group. One related problem in assessment of stereotype are centrality of the supposed characteristics - ambitious. As Lipmann is stating "a great deal of confusion arises when people decline to classify themselves as we have classified them. Prophecy would be so much easier if only they would stay where we put them. But, as a matter of fact, a phase like the working class will cover only some of the truth for a part of the time. When you take all the people, below a certain level of income, and call them the working class, you cannot help assuming that the people so classifies will behave in accordance with your stereotype. Just who those people and mine workers fit in more or less, but farms hands, small farmers, peddlers, little shop keepers, clerks, servants, soldiers, policemen, firemen slip out of the net" (Lipmann, 1998: 79).

The Lipmann observation leads us to the concern that persons acquire stereotypes in part, though personal experience. But because these stereotypes are part of the beliefs and shared assumptions that societies have about different types of people and groups, they are also part of the society collective knowledge.

In order for a society to socialize its members, stereotypes must be explicitly, even if subtlety, taught. Whether stereotypes are individual or cultural in origin, the emphasis on explicit beliefs is not surprising considering that the content of stereotypes has great intrinsic interest to both the person using the stereotype and the person targeted by it. Even when objectively wrong, stereotypes simplify social perception and serve as guidelines for social interaction (White, 2006: 3).

When individuals interact, in formal or informal groups, with people from diverse social categories, their differences are more likely to be salient and, therefore, more likely to activate social stereotypes associated with that category. For example, people from urbanized environment and people from periphery.

When stereotypes are well known, but individuals are not known personally to each other, those stereotypes may affect both how individuals treat one another and how they view themselves. Many stereotypes exist about particular occupations. Occupational stereotypes are often activated in situations where people from multiple occupations come together to work on a shared task, such as architects, engineers, and contractors on construction sites. But within a given occupation, occupational stereotypes can be activated when group members come from different environments (Leonardi, 2013: 3). It could be linked with environment that is characterized as office or clerical work in the building and agriculture or field work that is work in the open space.

Stereotypes may not be simply a view of the world that is either right or wrong, but linked into a person's understanding of wider perspective of the world. Stereotypes can be viewed as intergroup perception since people belong to number of social groups like family member, occupational group, etc. (Hinton, 2013: 105).

In accordance with occupational context stereotyping is the act of labeling or treating people with similar characteristics as though they all exhibit the same values, judgments, and behavior. Stereotyping develops 
from information we choose to hear and remember from our family, peers, religious establishments, teachers, community and the entertainment media (Young, 2012: 25). Since stereotyping by definition ignores individual differences it can be problematic situation if it refers to the workplace, like lady in the bank should look formal, military soldier is a powerful man. Gilmore and Hunt argued that in general practice professional stereotyping is common. Doctors and nurses saw social workers as 'trendies' who were unrealistic about health problems, while social workers saw doctors and nurses as authoritarian (Leathard, 2002: 137). The same stereotypic context can be reflected as regards farmer and other professions like agronomist or biologist.

Some other sociological approaches reflect that stereotypes are categorical units of negative beliefs that leads to discrimination. Discrimination against those who have not "measured up" begins to spread. Stereotypes therefore can be defined as stigmatized beliefs (Sociology, 2013: 138).

As described previously in the article stereotype is used to categorize a group of people. For example, urban youth don't understand farmers, so they put them into classifications, thinking that everyone who is that needs to be like that, or anyone who acts like their classifications is one. Therefore a social perception is used to reveal urban youth stereotypes of Farmer and Agriculture in the further subsections of article.

\section{Urban youth stereotypes of Farmer and Agriculture}

The observation behind the research on urban youth perception of the farmer is based on the theoretical approach of the term "stereotypes". Lippmann's notion of stereotypes as a short cut points to the manner which stereotypes are a very simple, striking, easily grasped form of representation but none the less capable of condensing a great deal of complex information and a host of connotations.

It is interesting revealing stereotypes of the Lithuanian and Latvian urban youth perception in order to find out the different assumptions of what farmer role is in accordance with occupational context.

As regards United Nations concept "Youth" is best understood as a period of transition from the dependence of childhood to adulthood's independence and awareness of our interdependence as members of a community (UN, 2013). Youth is best understood as a period of transition from the dependence of childhood to adulthood's independence. In this context certain cultural background can influence change of stereotypic thinking and can affect both the perceived and perceiver.

Keeping in mind that there are specificities in between urban and rural communities it was been essential to find out urban youth perceptions as regards farmer and agriculture. An urban community refers to a community that is mostly composed of residents in a cities or towns and is also referred to as a residential community.

According to the experiences, youth primarily make judgments about agriculture and the support mechanism attached to it through what they have read or stories reflected in media, often influenced by different opinions. There are many initiatives at a European Union level in the form of EU funded projects, web sites, blogs, discussion clubs, other activities dedicated to the youth. However it was been essential to find out how stereotypes function in urban youth thoughts. (In 2013 there was conducted research where 950 urban youth participated from Latvia and 908 from Lithuanian in order to share their views and thoughts in survey as regards perceptions on Farmer Portrait and Agriculture (Urban Youth Perceptions, 2013: 8). They indicated existing stereotypes about farmers and agriculture in Latvia and Lithuania. Overall youth did point that stereotypes exists while there are differences on evaluation of dissemination level. The question as regards stereotypes about farmers and agriculture exists in Latvia, Lithuania the majority of youth in both countries pointed "rather yes" - $45 \%$ (LV) and $34 \%$ (LT). Agreed that there are existing stereotypes where $20 \%$ of respondents (LV) and $27 \%$ (LT). Nevertheless some of the respondents didn't agree on the statement $19 \%$ (LT) and $29 \%$ (LV) and rather disagreed $20 \%$ (LT) and $29 \%(\mathrm{LV})$ of the youth.

Apart from quantitative data respondents did described characteristics of farmer role. The both Latvian and Lithuanian youth did pointed that farmers are persons who working hard and long hours; farmers are close to the nature and they like animals. Lithuanian youth did reflected that work in agriculture for several 
years was been unfashionable, but nowadays when European Union financial support is available it becomes more attractive. Youth from Latvia pointed out that farmers are patient in Latvia. They also described that farmer need to be educated in agriculture, chemistry and /or biology as well as more using technical skills of equipment in order to be successful.

Latvian respondents acknowledged that the work in the fresh air is one of the main advantages of the farmers. However, a number of young people do not see a prospect for agriculture and believes that hard work is not comparative with compensation.

Lithuanian youth reflected that agriculture is profitable, it has the potential. Overall young people think that farming is a natural way of life.

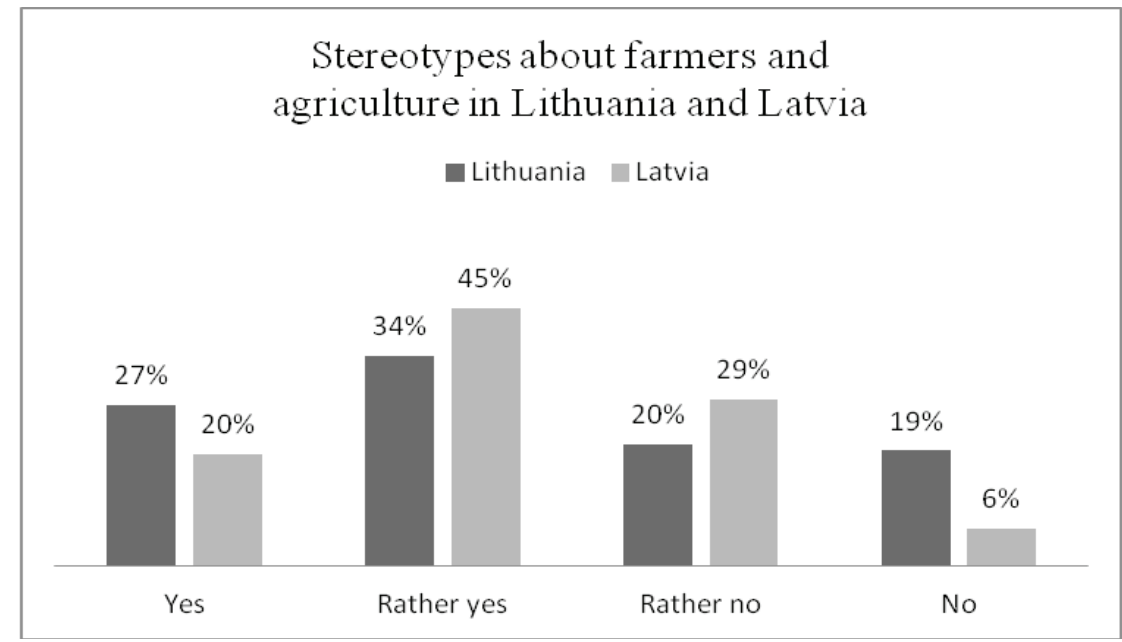

Figure 1. Stereotypes about farmers and agriculture in Latvia and Lithuania

Source: Urban Youth Perceptions, 2013: 17

As it was described in the Lipmann description of the term "stereotypes" it holds thoughts or beliefs that may or may not accurately reflect reality. Youth reflect reality from the perspective of life in the city they are living and creating "picture in their heads" keeping in mind urban environment. Nevertheless youth are influenced by the personal experience. Overall youth think that farming is hard, physical labor and stressful because of machinery breakage, weather uncertainties, and price variances. While these were little described advantages that agriculture might bring like research, engineering, financial management, or international commodity markets were described by youth.

Apart from the quantitative approach respondents did described their observation as regards specificity of the farmer and farming. The descriptions were diverse while the common part revealed occupational stereotype perspective.

Stereotypic categorization helps the human psyche to deal with uncertainties, to generalize from limited data, and to define the self and others. While in the same time stereotypes can be positive, neutral, or negative. Positive or negative characterizations and categorizations of a group of people based only on expectations or assumptions about the group rather than on individual who compose the group (Galician, 2013: 26).

The view of positive and negative stereotyping is analyzed in the Diaz, Saran work on "Beyond Stereotypes. Minority Children of Immigrants in Urban Schools". It was stated that positive or negative stereotyping justifies and rationalizes an individual's love-prejudice or hate-prejudice. Simultaneously, stereotyping as a continuous process of "selected perception" and "selective forgetting" that celebrates a group for its success but forgets their contribution if the group fails to achieve success (Diaz, Saran, 2010: 3).

In accordance with the research (Urban Youth Perceptions, 2013: 8) the most prevailing categories where possible to divide in 3 stereotype categories - positive stereotypes, negative stereotypes and neutral. 
The description of negative stereotypes in the research reflected more that positive ones since negative perception and judgments seem easier to develop for youth. Also it is more likely that those youth who didn't had any experience or relation with farming or agricultural issues made more negative stereotypes than those who had heard or seen more on the everyday life of the farm.

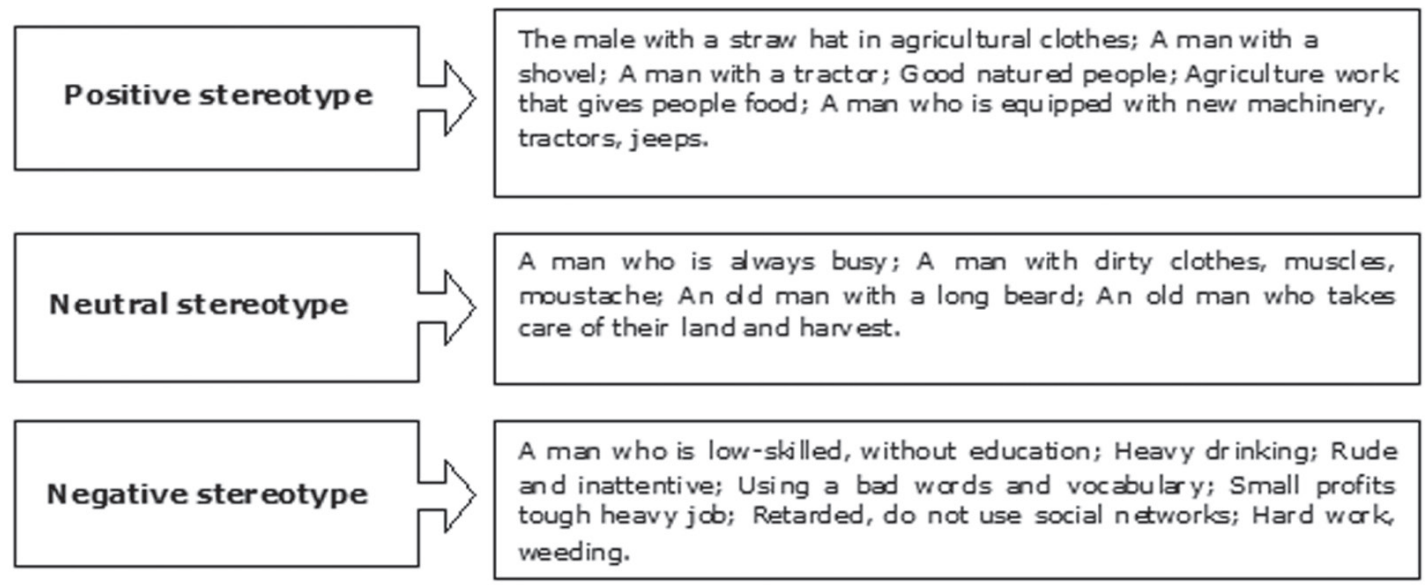

Figure 2. Stereotypic categorization

Source: Urban Youth Perceptions, 2013: 8

Overall people use stereotypes as a simplification tool which helps them in their everyday life to make decisions faster. Stereotypes can never illustrate the objective variation that exists but doubtlessly they contain a grain of truth.

In accordance with expert view on the urban youth perceptions on Farmer Portrait there were more fundamental views that arises of stereotypes and might be influenced by the mass media. "Media and advertising in creating a flavor or backdrop for drama and advertising, they hold outdated or misconceived ideas" (Urban Youth Perceptions, 2013: 13).

Some others did pointed the role of journalists might affect youth perceptions. "I think if journalists have to report about farmers and agriculture they start consciously or unconsciously from those stereotypes and although they try to describe an objective picture, in some respect the stereotype will be a part of it. A special case is a - unfortunately - very successful TV series called "Bauer sucht Frau" (farmer seeks woman), in which trough the special selection of participants I fear the first stereotype is encouraged" (Urban Youth Perceptions, 2013: 13).

In accordance with the research (Urban Youth Perceptions, 2013: 14) experts did pointed that youth is thinking of old stereotype about farmers that are not linked with modern life of the farmer. Also there where statement that the youth stereotypes hold one sight, only a bit of a truth and not fit "the farmers" in whole.

In accordance with Lipmann the term "stereotype" has journalistic origins. First of all, a stereotype was a kind of printing stamp to make multiple copies from a single model. Lipmann did used the term metaphorically in his book "Public Opinion" to describe the way as a society and as individuals categorize people "stamping" human beings with a set of characteristics and creating a "picture" inside our heads. But these pictures don't necessarily correspond to the world outside our head (Galician, 2013: 26). The summary at some point could be applied to the youth perception of the farmers and agriculture covering all four characteristics of stereotypes by Lipmann because they are - simple (they are formulated in a simple manner and can be identified in some sentences); they are absorb from cultural mediators like mass media (work of journalists, TV shows, advertisements etc.); since stereotypes are described as possibilities they are more or less false. Overall stereotypes are resistant to change like stereotype about farmer in rubbery boots or unskilled and uneducated farmers. 
Conclusion

1. Even from one side stereotypes are described as simplification tool that help people in their everyday life to make decisions faster while consequences of stereotype's dissemination could rise a wrong picture and opinion of farmers and their work, that could lead to the misunderstanding at a policy, economical and social basis.

2. Agriculture, for decades, had been associated with the production of basic food. Therefore agriculture plays a crucial role in the life of an economy. It is the backbone of our economic system. Agriculture not only provides food and raw material but also employment opportunities to a very large proportion of population.

3. Based on theory stereotypic categorization helps the human psyche to deal with uncertainties, to generalize from limited data, and to define the self and others. While problem is that a general stereotype influences the way we think and talk about individual members of a social group.

4. Mass media is not creating stereotypes as such while the main role of the media is to reinforce stereotypes.

5. In accordance to the research on Urban Youth Perceptions experts and youth did agreed that the media, notably entertainment industry and local television, print magazines, journals are the biggest sources of public information for youth that is disseminating various contexts also stereotypic view.

6. Stereotyping develops from information that youth choose to hear and remember from family, peers, religious establishments, teachers, community and the entertainment media.

7. Overall stereotypical youth views of agriculture prevail. Youth equated agriculture with farming, with old stereotypes (due to the reflection from experts some of the stereotypes were classified as "old", could be linked with the fairy tales or survived assumptions from older generations) that in some cases do not exist or do not correspond to situation in the modern farming. Some of the youth did made connection to the technical or research aspects of agriculture while youth do not see large potential that agriculture could bring for example via research, engineering, financial management etc.

8. On the basis of the research data, can be concluded that Latvian urban youth develop stereotyped view of the countryside and farming sector.

9. Since changing stereotypes is a difficult and time consuming it is advisable to disseminate not only information campaigns like "Back to Countryside" but also organize trips for school children to farms, arrange "green lessons" to discover work and main tasks in the organic farms to involve youth in the farm works.

\section{References}

Debating Europe. Arguments for and against the Common Agricultural Policy. (2014). Retrieved: http://www.debatingeurope.eu/focus/arguments-for-and-against-the-common-agricultural-policy/\#.U3wqVihedJI [access 04.03.2014].

Diaz, R., Saran, R. (2010). Beyond Stereotypes. Minority Children of Immigrants in Urban Schools. Canada: Sense Publishers, p. 248.

Dyer, R. (1999). The Role of Stereotypes. 2nd Edition. UK: Edinburgh University Press. Retrieved: http://thowe.pbworks.com/f/dyer.on.sterotypes.pdf [access 04.02.2014].

Engel, R. J. (2009). Fundamentals of Social Work Research. UK: Sage Publications, p. 396.

Galician, M. L. (2013). Analysis and Criticism of Unrealistic Portrayals and Their Influence: Sex, Love, and Romance in the Mass Media. UK: Routledge, p. 318.

Garcia, S. (2010). Rethinking Walter Lippmann's legacy in the history of public relations. Central Washington University. Retrieved: http://www.prismjournal.org/fileadmin/Praxis/Files/Journal_Files/2010_general/Garcia.pdf [access 04.02.2014].

Helmreich, W. B. (2004). The Things They Say Behind Your Back: Stereotypes and the Myths Behind Them. Transaction Publishers, p. 276.

Hinton, P. R. (2013). Stereotypes, Cognition and Culture. USA: Psychology Press, p. 219. 
Hogg, M. A., Reid, S. A. (2006). Social identity, self-categorization, and the communication of group norms. Communication Theory, Vol. 16, p. 7-30.

Leathard, A. (2002). Going Interprofessional: Working Together for Health and Welfare. UK: Routledge, p. 264.

Leonardi, P. M. (2013). Occupational Stereotypes, Perceived Status Differences, and Intercultural Communication in Global Organizations. Northwestern University, p. 35. Retrieved: http://comm.soc.northwestern.edu/leonardi/ files/2013/06/stereotypes.pdf [access 27.04.2014].

Lippmann, W. (1998). Public Opinion with a new introduction by Michael Curtis. New Jersy: Transaction Publishers, p. 427.

Miller, T., Birch, M., Mauthner, M., Jessop, J. (2012). Ethics in Qualitative Research Second edition, UK: Oxford Brookes University, p. 208.

Oskamp, S., Schultz, R. W. (2005). Attitudes and Opinions. Third Edition. USA: Lawrence Erlbaum Associates, p. 567.

Sampling. Chapter 5. (2008). Sage Publications, p. 42. Retrieved: http://www.sagepub.com/upm-data/24480_Ch5.pdf [access: 04.06.2014].

Seiter, E. (2006). Stereotypes and the Media: A Re-evaluation. Journal of Communication, Vol. 36, Issue 2, p. 14-26.

Turner, J. H. (2012). Theoretical Principles of Sociology, Vol. 3, p. 448. Mesodynamics, UK: Springer.

Turner, J. H., Beeghley, C. H. (2011). The Emergence of Sociological Theory. UK: SAGE, p. 520.

UN Social and Human Sciences. Retrieved: www.unesco.org/new/en/social-and-human-sciences/themes/youth/youthdefinition [access 06.05.2014].

White, M. J. (2006). Implicit and Explicit Occupational Gender Stereotypes. Springer Science, Vol. 55, No. 3-4, p. 259.

Why do we need Common Agriculture Policy? (2009). Discussion paper DG AGRI. European Commission. Retrieved: http://ec.europa.eu/agriculture/cap-post-2013/reports/why_en.pdf [access: 27.01.2014].

Young Farmers Statistics. European Council of Young Farmers. Retrieved: http://www.ceja.eu/en/policy-and-publications/statistics-on-young-farmers/young-farmers-statistics [access 04.05.2014].

Young, K. S., Travis, H. P. (2012). Business and Professional Communication: A Practical Guide to Workplace Effectiveness. Waveland Press, p. 237.

Zemgale NGO Centre. (2013). Research on Urban Youth Perceptions on Farmer Portrait. In accordance with EC CAP project „CAP-Back to Countryside” AGRI-2013-0086. Retrieved: www.zemgalei.lv [access: 27.01.2014].

\section{LIETUVOS IR LATVIJOS MIESTU JAUNIMO STEREOTIPAI, SUVOKIMAS APIE ŽEMDIRBIUS IR ŽEMÉS ŪKI}

Janis Kusis, Baiba Miltovica, Linda Feldmane

Latvijos žemės ūkio universitetas, Socialinių ir humanitarinių mokslų institutas (Latvija)

\section{Santrauka}

Straipsnyje teoriškai nagrinejjami profesiniai stereotipai. Šis terminas sociologų ir ekonomistų darbuose, kuriuose nagrinejjama su žemės ūkiu susijusi tematika, retai aptinkamas. Straipsnyje naudojami W. Lipmann, R. Dyer, S. Oskamp, R. W. Schultz ir kt. aprašyti stereotipų elementai. Stereotipai - tai perdèti supaprastinimai ar apibendrinimai, kurie yra daug sudètingesni, nei gali pasirodyti iš pirmo žvilgsnio. Šiame straipsnyje nagrinėjama, kaip stereotipai funkcionuoja socialinejje mintyje ir kaip veikia miestų jaunimo mąstymą. Skiriami neigiami, neutralūs ir teigiami stereotipai. Siekiant parodyti, kokie stereotipai būdingi Lietuvos ir Latvijos miestų jaunimui, kaip jie suvokia žemdirbius ir žemès ūkį, straipsnyje taikomi kiekybiniai ir kokybiniai tyrimo metodai.

PAGRINDINIAI ŽODŽIAI: stereotipas, profesiniai stereotipai, miesto jaunimas.

JEL KLASIFIKACIJA: Q18 